\title{
Communication
}

\section{Reconstitution of UV-damaged DNA into chromatin using Xenopus oocyte extracts ${ }^{\star \bullet}$}

\author{
Piotr Widłak
}

Department of Experimental and Clinical Radiobiology, Institute of Oncology, Gliwice, Poland

Key words: nucleosomes, Xenopus oocyte extracts, DNA repair, ultraviolet radiation, DNA photoproducts

\begin{abstract}
Chromatin was reconstituted in vitro using Xenopus oocyte extracts and plasmid DNA containing UV radiation-induced damage. Damaged DNA was assembled into minichromosomes with an efficiency similar to that of control, non-irradiated DNA. Oocyte extracts were competent to carry out DNA repair, which was elicited by nicking damaged templates followed by DNA synthesis during chromatin assembly. Newly synthesized DNA was efficiently reconstituted into nucleosomes.
\end{abstract}

The packaging of eukaryotic DNA into nucleosomes and their organization into higher order chromatin structures adds levels of complexity to the mechanism of DNA repair. It is well documented that nucleotide excision repair, an important DNA repair pathway (rev. in [1, 2]), is associated with severe rearrangements of chromatin structure. Repairconnected chromatin alterations can be considered in two aspects: remodeling of nucleosomes that facilitates the access of the repair machinery to the site of damage, and second, reassembly of repaired DNA to restore the preexisting chromatin structure (rev. in [3]). Thus it becomes clear that before we are able to fully understand DNA repair processes in eukaryotic cells, we need to know how DNA damage and repair affect chromatin structure.

A number of investigators have studied how DNA lesions affect nucleosome formation. Most of them utilized UV-irradiation as a

\footnotetext{
"Paper presented at the Conference on "Mechanisms of DNA Repair and Mutagenesis" Commemorating the $100^{\text {th }}$ Anniversary of the Discovery of Polonium and Radium, October, 1997, Warsaw, Poland. 'The work was sunported by the State Committee for Scientific Research (KBN, grant 6P04A04112).

${ }^{8}$ Address for correspondence: Department of Experimental and Clinical Radiobiology, Institute of Oncology, Gliwice, Wybrzeże Armii Krajowej 15, 44-100 Gliwice, Poland; fax: (32) 313 512; e-mail: widlak@onkol.instonko.gliwice.pl
}

Abbreviations: CPD, cyclobutane pyrimidine dimers; 6-4PP, pyrimidine-pyrimidone (6-4) photoproducts; MNase, micrococcal nuclease. 
DNA-damaging agent, that is known to induce two major forms of damage: cyclobutane pyrimidine dimers (CPD) and pyrimidinepyrimidone $(6-4)$ photoproducts (6-4PP) (rev. in [4]). The data obtained in such studies are divergent, probably due to different experimental systems used for chromatin reconstitution and analyses. An octamer exchange reaction was utilized to reconstitute chromatin from purified histones on two nucleosome positioning sequences: $5 \mathrm{~S}$ rDNA [5] and $\mathrm{HI}-$ SAT from the yeast $D E D 1$ promoter [6]. The presence of UV-induced damage decreased histone binding to $5 \mathrm{~S}$ rDNA, while it did not affect histone binding to the HISAT sequence. Furthermore, the presence of preexisting CPDs affected the nucleosome rotational setting placing the lesion away from histone surface $[6,7]$. Studies on minichromosomes formed from plasmid DNA and purified core histones pretreated with polyglutamic acid showed that UV-irradiated DNA was less efficiently assembled into nucleosomes, and irradiation of the reconstituted chromatin resulted in partial disruption of nucleosomes [8, 9]. Unlike the experiments described above, in which nucleosomes were reconstituted from purified components, circular DNA molecules that contained UV-induced lesions were efficiently assembled into chromatin either after injection into Xenopus oocyte nuclei [10] or reconstituted with cell-free extracts from Xenopus oocytes [11]. It was observed that repair DNA synthesis occurred simultaneously with a chromatin assembly [10]. More recently, it was shown that a chromatin assembly factor I (CAF-I) was necessary for such repair associated chromatin reconstitution [12, 13].

In the present study I have characterized minichromosomes assembled in vitro in the Xenopus oocyte system on a DNA template containing UV-induced lesions. I have also aimed to examine whether minichromosomes purified from this system could serve as tem- plates for nucleotide excision repair catalyzed by yeast or human extracts.

\section{MATERIALS AND METHODS}

Plasmid templates. Single-site labeling of circular DNA utilized the procedure of Shimamura and coworkers [14], with some modifications [15]. Briefly, pUC19 was linearized with $E c o$ RI restriction enzyme and treated with alkaline phosphatase. DNA was then purified by phenol/chloroform extraction followed by ethanol precipitation and labeled with $[\gamma$ ${ }^{32}$ P]ATP using T4 polynucleotide kinase. DNA circles were generated in a T4 DNA ligase-catalyzed reaction. The samples of plasmid (either labeled or non-radioactive) were UV-irradiated on ice as $10-20 \mu \mathrm{l}$ droplets, at $254 \mathrm{~nm}$ using a UV-crosslinker (Stratagene).

Preparation of oocyte extract and assembly of minichromosomes. Xenopus laevis oocyte extract was prepared according to Shimamura and coworkers $[14,16]$. Briefly, ovaries were treated for $3 \mathrm{~h}$ with $0.15 \%$ collagenase type II in buffer OR-2 (5 mM Hepes, $1 \mathrm{mM}$ $\mathrm{Na}_{2} \mathrm{HPO}_{4}, 82 \mathrm{mM} \mathrm{NaCl}, 2.5 \mathrm{mM} \mathrm{KCl}, 1 \mathrm{mM}$ $\mathrm{CaCl}_{2}, 1 \mathrm{mM} \mathrm{MgCl}_{2}, \mathrm{pH}$ 7.6) and washed with 10 changes of OR-2. Small oocytes were discarded and large stage- 6 oocytes were mixed with an equal volume of extraction buffer (20 $\mathrm{mM}$ Hepes, $5 \mathrm{mM} \mathrm{KCl}, 1.5 \mathrm{mM} \mathrm{MgCl}_{2}, 1 \mathrm{mM}$ EGTA, $10 \%$ glycerol, $10 \mathrm{mM} \beta$-glycerophosphate, $0.5 \mathrm{mM}$ dithiothreitol, $\mathrm{pH}$ 7.4) and centrifuged for $90 \mathrm{~min}$ at $150000 \times \mathrm{g}$ at $4^{\circ} \mathrm{C}$, then the supernatant was collected. Assembly of circular plasmid into chromatin was done according to the protocols of Shimamura and coworkers [14, 16], in a final volume of $10-100$ $\mu \mathrm{l}$. A $10 \mu \mathrm{l}$ reaction mixture consisted of $4 \mu \mathrm{l}$ oocyte extract, $20 \mathrm{ng}$ circular DNA (either radioactive or non-radioactive), $10 \mathrm{ng}$ creatine phosphokinase and $40 \mathrm{mM}$ creatine phosphate, $3 \mathrm{mM}$ ATP, $5 \mathrm{mM} \mathrm{MgCl}_{2}$ in extraction buffer. The mixture was incubated for $2 \mathrm{~h}$ at 
$37^{\circ} \mathrm{C}$. To analyze DNA synthesis during the incubation, the non-radioactive plasmid was assembled in the presence of $6.7 \mathrm{nM}[\alpha$ $\left.{ }^{32} \mathrm{P}\right] d \mathrm{CTP}$ ( $\left.3000 \mathrm{Ci} / \mathrm{mmol}\right)$.

Analysis of nucleosome formation. Supercoils introduced into DNA upon nucleosome formation were analyzed by agarose gel electrophoresis. Aliquots of the assembly reaction mixture were added to $1 / 2$ volume of stop solution $(0.6 \%$ SDS, $50 \mathrm{mM}$ EDTA and $6 \mathrm{mg} / \mathrm{ml}$ proteinase $\mathrm{K}$ ) and incubated for $1 \mathrm{~h}$ at $50^{\circ} \mathrm{C}$. Gel loading dye-buffer was added and samples were then run on $1.5 \%$ agarose gels ( $1 \times$ TEA). Alternatively, electrophoresis was performed in the presence of $30 \mu \mathrm{M}$ chloroquine. Some DNA samples were electrophoresed in two dimensions. After the $1^{\text {st }}$ dimension, gels were soaked in chloroquine-containing buffer, turned by $90^{\circ}$ and run in the $2^{\text {nd }}$ dimension. When electrophoresis was completed gels were fixed in $1 \%$ cetyltrimethylammonium bromide, dried and exposed to X-ray films or PhosphorImager screens. To analyze the nucleosomal ladders of minichromosomes, $\mathrm{CaCl}_{2}$ (final concn. $3 \mathrm{mM}$ ) and micrococcal nuclease (final concn. 0.2 units $/ \mu$ l) were added to the assembly mixture. Digestion proceeded for 1-90 $\mathrm{min}$ at room temperature and was stopped by adding $1 / 2$ volume of stop solution (see above). After incubation at $50^{\circ} \mathrm{C}$ samples were run on $1.5 \%$ agarose gels ( $1 \times \mathrm{TEA})$ and gels were fixed, dried and exposed as described above.

Assay of DNA adducts. DNA was assayed for the presence of UV-adducts according to the ${ }^{32} \mathrm{P}$-postlabeling method [17]. Briefly, DNA was digested to mononucleotides and photoadduct-containing trinucleotides with DNase I and snake venom phosphodiesterase. Samples were dephosphorylated with prostatic acid phosphatase and then enzymes were removed by proteinase $\mathrm{K}$ treatment and ethanol precipitation. After evaporation of ethanol, trinucleotides were ${ }^{32}$ P-labeled in a $\mathrm{T} 4$ polynucleotide kinase catalyzed reaction, applied to PEI-cellulose thin-layer plates and developed by two dimensional-chromato- graphy. Adduct spots were visualized by autoradiography and quantitated by scintillation counting. In each experiment levels of adducts were calculated according to the recovery of a synthetic trinucleotide standard containing thymidine dimers.

\section{RESULTS AND DISCUSSION}

\section{Formation of UV-induced DNA lesions}

Plasmid DNA irradiated at different doses of UV-C was analyzed for the presence of photoproducts using the method of ${ }^{32} \mathrm{P}$-postlabeling [17]. Figure 1A shows autoradiograms of control and UV-irradiated DNA samples, and of a synthetic trinucleotide containing thymidine dimers (control, non-irradiated samples also contained small yet detectable amounts of photoproducts - visible after longer exposure of plates). In agreement with a previous study [18], contribution of cyclobutane pyrimidine dimers to the total number of adducts was about $80 \%$ and was not significantly changed with increasing UV doses (not shown). I estimate that at a $100 \mathrm{~J} / \mathrm{m}^{2}$ dose each plasmid molecule should possess on average about 1.3 adducts. The amount of total UV-photoproducts reached a plateau at a $1 \mathrm{~kJ} / \mathrm{m}^{2}$ dose (Fig. 1B). Plasmid DNA irradiated at $5 \mathrm{~kJ} / \mathrm{m}^{2}$ should possess about one photoproduct for every 1000 bp (2.6 lesions per plasmid molecule, on the average), that is values significantly lower than numbers estimated from immunoassays [8] and $\mathrm{T} 4$ endonuclease $\mathrm{V}$ cleavage [5] (5-20 times less at comparable UV doses).

\section{Xenopus oocyte extracts efficiently assem- bled lesion-containing DNA}

To study the rate of chromatin reconstitution I followed the change in the topological properties of circular DNA. When nucleosomes are assembled on circular DNA in the presence of topoisomerase, the change in link- 


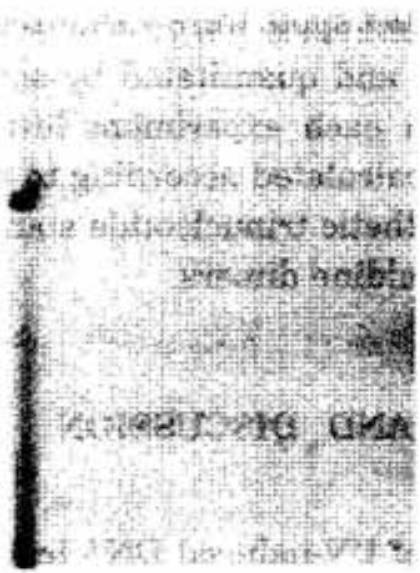

Control DNA

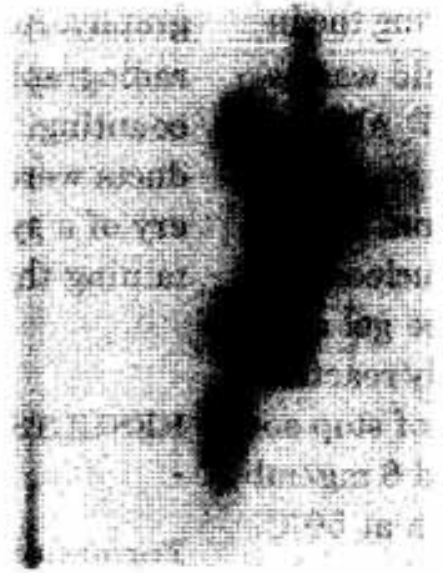

Irradiated DNA

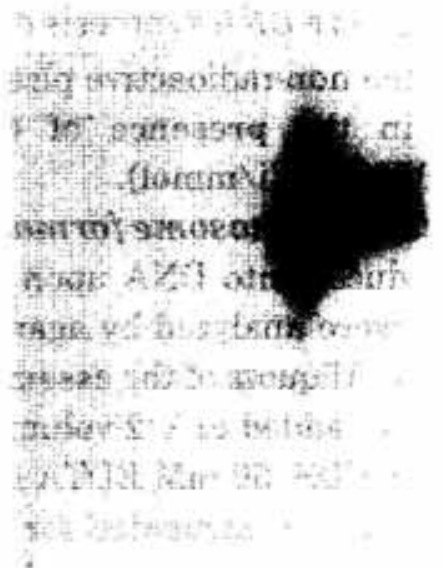

Standard A.

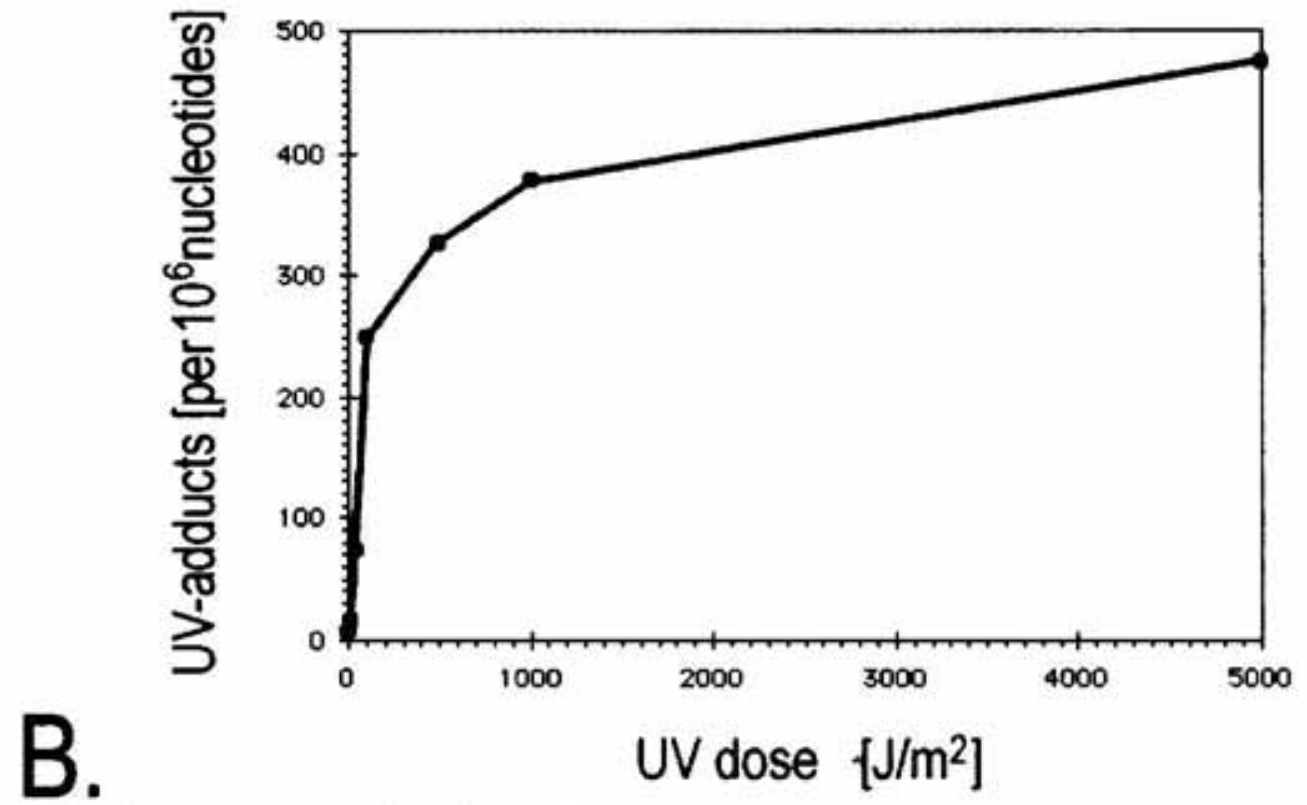

Figure 1. DNA photoproducts induced by UV-irradiation.

Panel A: Chromatograms of control (non-irradiated) and UV-irradiated (at a $100 \mathrm{~J} / \mathrm{m}^{2}$ dose) plasmid DNA, and a standard trinucleotide containing thymidine dimers. Panel B: The level of total DNA photoproducts induced at different doses of UV-radiation.

ing number of isolated DNA corresponds to the number of nucleosomes assembled prior to deproteinization [19]. Different plasmid topoisomers were separated by agarose gel electrophoresis (the use of chloroquine, a DNA intercalating agent, enabled better separation of negatively supercoiled topoisomers and distinguished between nicked and relaxed closed circular forms). Irradiation of DNA at doses up to $500 \mathrm{~J} / \mathrm{m}^{2}$ did not affect the distribution of negatively supercoiled topoisomers, and after $2 \mathrm{~h}$ of assembly with oocyte extracts, covalently closed DNA become fully converted into negatively supercoiled forms (Fig. 2A and 2B; lanes 1-5). When DNA irradiated at higher UV-doses ( 1 and $5 \mathrm{~kJ} / \mathrm{m}^{2}$ ) was assembled, less material was present as fully supercoiled forms, however relaxed forms were also undetectable (lanes 6, 7), as in the case of low UV doses. To study the rate of chromatin assem- 

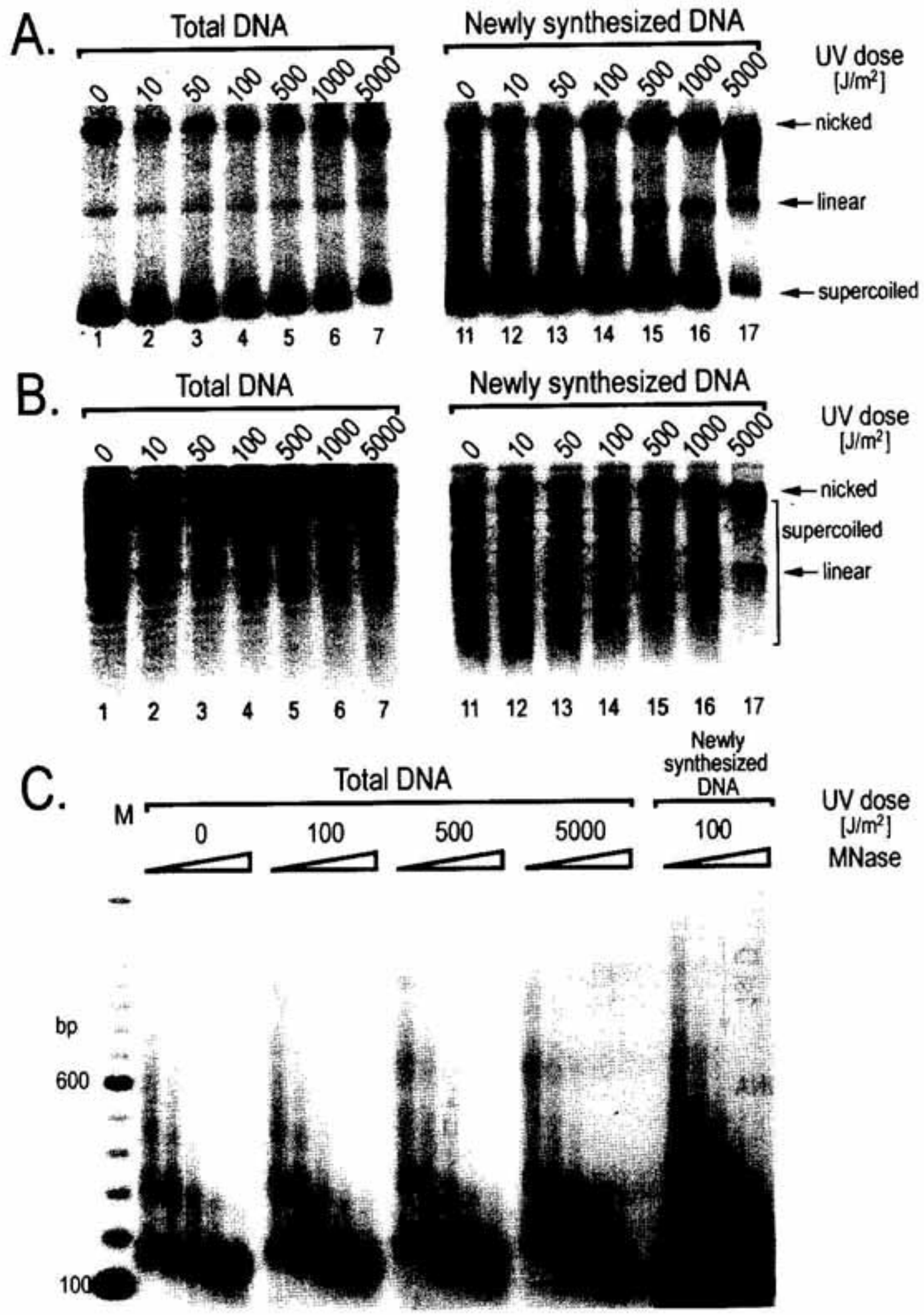

Figure 2. UV-damaged DNA is assembled into minichromosomes with Xenopus oocyte extracts.

Plasmid DNA irradiated at different doses of UV $(254 \mathrm{~nm})$ was incubated with oocyte extract, then DNA supercoiling was analyzed by agarose gel electrophoresis in the absence (panel A) and presence (panel B) of chloroquine. Plasmid was labeled at a single specific site (see Methods section) and visualized by means of autoradiography. To analyze newly synthesized DNA, assembly of non-radioactive plasmid was carried out in the presence of radioactive precursors and autoradiography was performed. The positions of different DNA circular and linear forms are indicated. MNase digestion pattern of reconstituted minichromosomes is shown in panel C. Lane M represents a marker 100 bp-ladder. 


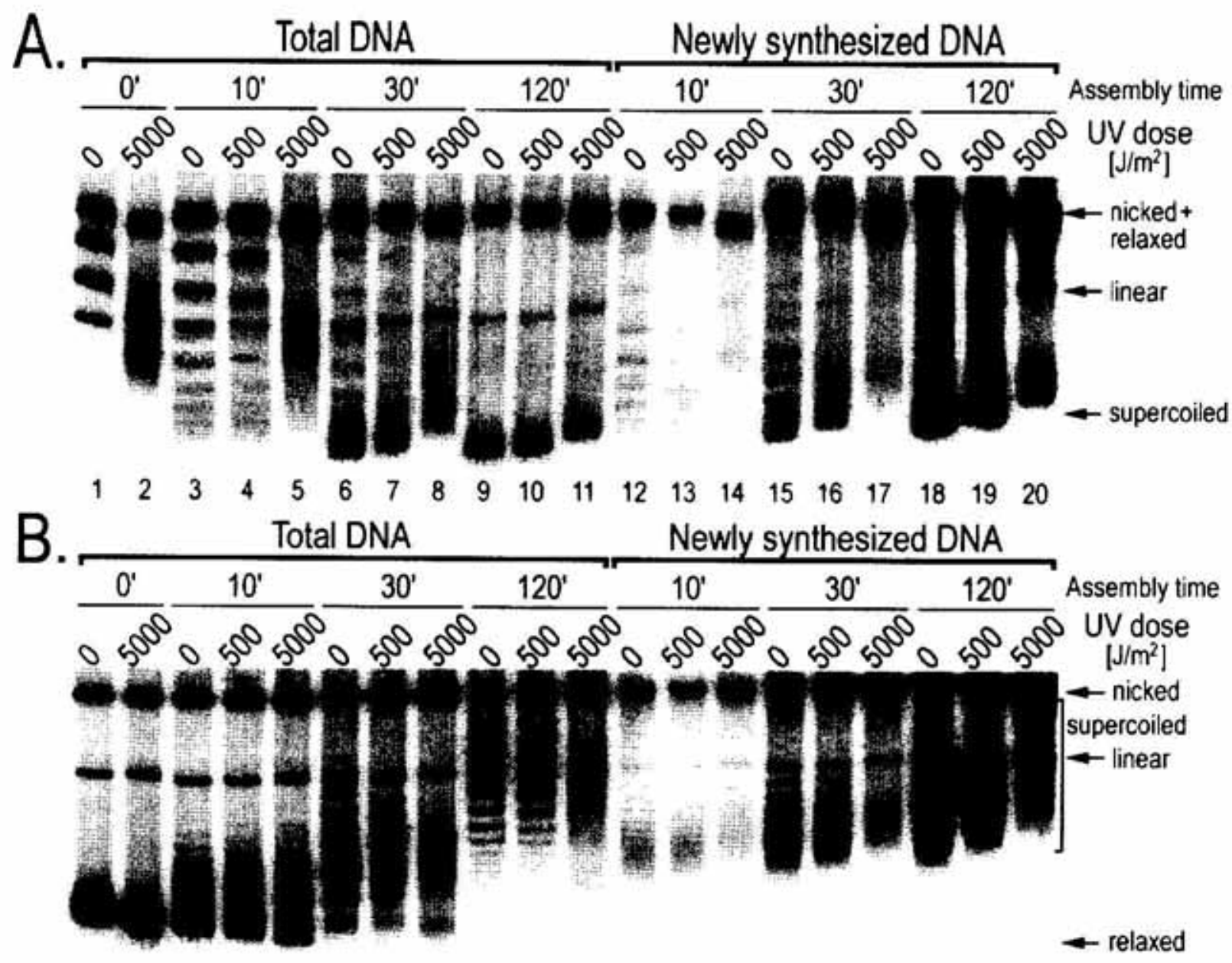

$\begin{array}{llllllllllllllllllll}1 & 2 & 3 & 4 & 5 & 6 & 7 & 8 & 9 & 10 & 11 & 12 & 13 & 14 & 15 & 16 & 17 & 18 & 19 & 20\end{array}$

C.

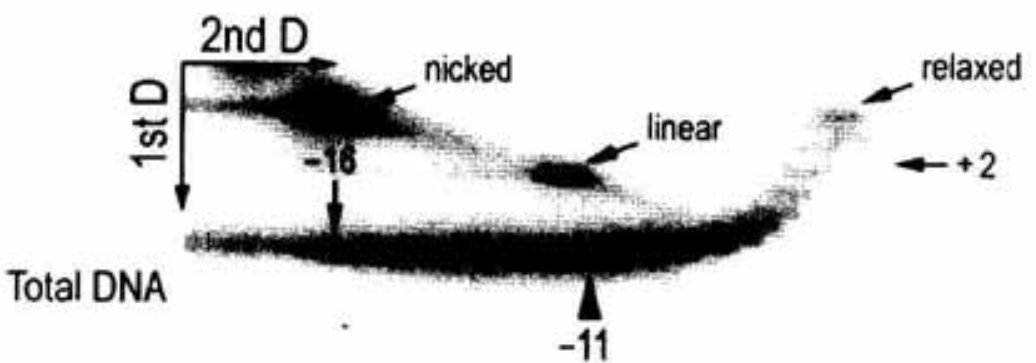

Newly synthesized

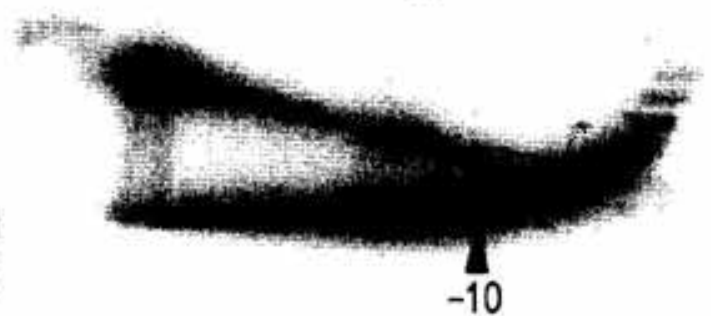

Figure 3. Newly synthesized DNA is efficiently assembled into chromatin.

Plasmid DNA (either control or UV-irradiated at 500 and $5000 \mathrm{~J} / \mathrm{m}^{2}$ ) was incubated with oocyte extract for 10,30 or $120 \mathrm{~min}$. DNA supercoiling was analyzed by agarose gel electrophoresis in the absence (panel A) and presence (panel B) of chloroquine, in either total or newly synthesized DNA (as in Fig. 2). Supercoils in a plasmid irradiated at $100 \mathrm{~J} / \mathrm{m}^{2}$ and assembled for $1 \mathrm{~h}$ (in either total or newly synthesized DNA) were analyzed by two-dimensional electrophoresis (panel C). Marked are supercoils of different topoisomers. 
bly, DNA topoisomers were analyzed after 10 , 30 and $120 \mathrm{~min}$ of incubation (Fig. $3 \mathrm{~A}$ and $3 \mathrm{~B}$; lanes 1-11). Control, non-irradiated DNA and plasmid irradiated at a $500 \mathrm{~J} / \mathrm{m}^{2}$ dose were assembled into nucleosomes at similar rates. The presence of the photoproducts affected the electrophoretic mobility of topoisomers that was clearly visible in samples irradiated at $500 \mathrm{~J} / \mathrm{m}^{2}$, or even resulted in loss of discrete electrophoretic bands that caused a smear of topoisomers in samples irradiated at $5 \mathrm{~kJ} / \mathrm{m}^{2}$ (visible also in Fig. 2). Lesion-induced changes of electrophoretic mobility of topoisomers seem not to be specific for UV-photoproducts since similar effects were observed in samples damaged with $N$-acetoxyacetylaminofluorene (not shown). This emphasizes that analysis of data from DNA supercoiling assays could lead to misinterpretations in the case of damaged DNA. To verify that supercoiling of the plasmid was due to chromatin reconstitution, samples assembled for $2 \mathrm{~h}$ were digested with micrococcal nuclease (MNase), which cleaved linker DNA and generated a characteristic ladder (Fig. 2C). The analysis of the MNase ladder showed that the size of the protected mononucleosome DNA was close to $146 \mathrm{bp}$, as expected for core particles, whereas oligonucleosomes exhibited repeat lengths of about $160 \mathrm{bp}$. MNase digestion of minichromosomes assembled on either control DNA or plasmid irradiated at 100,500 and $5000 \mathrm{~J} / \mathrm{m}^{2}$ generated similar nucleosomal ladders. This confirms that Xenopus oocyte extracts were competent to reconstitute DNA containing UV-induced photoproducts into nucleosomes.

\section{DNA synthesis occurs during chromatin as- sembly and newly synthesized DNA is effi- ciently reconstituted into nucleosomes}

Since nucleotide excision repair can be analyzed by means of associated DNA synthesis, the incorporation of labeled nucleotide into damaged templates was studied during incubation with oocyte extracts. To quantitate the rate of radioactive precursor incorporation, DNA was linearized after deproteinization, run on agarose gels and then radioactivity was calculated using ImageQuant software (Molecular Dynamics) from PhosphorImager screens (not shown). Incorporation of radioactive nucleotides during incubation with oocyte extracts was detected in control, nonirradiated samples. Incubation of UVirradiated DNA resulted in a further increase of incorporated label, that was in proportion to UV doses. However, the increase of radioactivity in UV-irradiated samples over the "background" level of a control was relatively small (1.06, 1.15, 1.21, 1.43, 1.69 and 1.80 fold increase at 10, 50, 100, 500, 1000 and 5000 $\mathrm{J} / \mathrm{m}^{2}$, respectively). When the rate of label incorporation into control and UV-irradiated plasmid was compared, faster incorporation into irradiated DNA was detected after shorter times of incubation (2.9 and 1.8 fold higher as compared to control after $10 \mathrm{~min}$ and $2 \mathrm{~h}$, respectively, for DNA irradiated at $5 \mathrm{~kJ} / \mathrm{m}^{2}$ ). The relatively high rate of DNA synthesis in control, non-irradiated samples was probably due to repair of nicks that were introduced into DNA during the procedure of template preparation (see below). The comparison of total and newly synthesized DNA revealed similar distributions of topoisomers (Fig. 2, lanes 1-7 and 11-17; Fig. 3, lanes 3-11 and 12-20), suggesting that repaired DNA was assembled into nucleosomes with an efficiency similar to that of total DNA. However, newly synthesized DNA was detected only as negatively supercoiled but not as covalently closed relaxed circles (compare lanes 3-5 and 12-14 in Fig. 3B). To more carefully compare the distribution of topoisomers in total and newly synthesized DNA, appropriate samples were run on two-dimensional agarose gels (Fig. $3 \mathrm{C}$ ). The analysis showed similar linking numbers of the most abundant topoisomers of total and newly synthesized DNA ( -11 and -10 , respectively). This confirmed that the repaired DNA was assembled into nucleosomes at similar (yet slightly slower) rates 
as compared to total DNA. The assembly of newly synthesized DNA into chromatin was verified by MNase digestion (Fig. 2C). Since the radioactive label was present in mononucleosomes, it could be concluded that repaired DNA was reconstituted also into core particles.

\section{Lesion-containing DNA is nicked during in- cubation with oocyte extracts}

Because of uncompleted ligation during preparation of the template a portion of the plasmid existed as nicked and linear forms (about $29 \%$ and $3 \%$, respectively). UV-irradiation of the plasmid hardly increased the contribution of these forms (about 34\% nicked and $4 \%$ linear DNA, at the highest $5 \mathrm{~kJ} / \mathrm{m}^{2}$ dose; see lanes 1 and 2 in Fig. 3B). Thus UVirradiation by itself did not introduce significant amounts of single- and double-strand breaks into DNA. When plasmid irradiated at doses higher than $100 \mathrm{~J} / \mathrm{m}^{2}$ was incubated with Xenopus oocyte extracts, the proportion of nicked (but not linear) form increased significantly $(32 \%, 39 \%, 47 \%$ and $68 \%$ at 100,500 , 1000 and $5000 \mathrm{~J} / \mathrm{m}^{2} \mathrm{UV}$, respectively; see also Fig. 2A). Analysis of newly synthesized DNA revealed similar increases in the contribution of nicked circles. However, while at low and moderate UV-doses (up to $500 \mathrm{~J} / \mathrm{m}^{2}$ ) slightly less of nicked circles was detected in newly synthesized DNA as compared to total DNA, at high doses the number of molecules that carried single-strand breaks was higher $(79 \%$ at $5 \mathrm{~kJ} / \mathrm{m}^{2}$ ). The introduction of single-strand breaks into lesion-containing DNA during incubation with Xenopus oocyte extracts probably resulted from "incision/excision" step of nucleotide excision repair.

\section{Xenopus oocyte extracts are proficient to re- pair UV-induced DNA photoproducts}

Cell-free extracts from Xenopus oocytes were able to carry out repair synthesis upon UVdamaged DNA templates, in agreement with earlier data obtained for Xenopus egg extracts [12] and injected oocytes [10]. Furthermore, the formation of single-strand breaks was observed during incubation of damaged DNA with such extracts. Thus, one can conclude that nucleotide excision repair occurs in cellfree Xenopus oocyte extracts. However, the presence of unsealed nicks in DNA undergoing repair suggested that the ligation step was less efficient as compared to the incision/excision steps. Repair in these extracts (in the given experimental conditions) apparently could not be fully completed when there was one UV-photoproduct per every 1-2 kb (that means > $1.5 \mathrm{nM}$ concentration of UVphotoproducts in the reaction mixture). Therefore, analysis of nicks introduced into circular DNA might be considered to reflect the incision/excision steps in systems that are able to carry out nucleotide excision repair in vitro. UV-damaged DNA was efficiently assembled into nucleosomes when incubated with cell-free extracts from Xenopus oocytes or eggs ([10-12], this study), in opposition to the experiments in which chromatin was reconstituted from purified histones $[5,8,9]$. This was probably due to repair processes occurring in such cell-free extracts. On the other hand, because of this repair activity, minichromosomes reconstituted on damaged DNA in Xenopus oocyte extracts might not be recommended as chromatin templates for subsequent study of their repair in yeast or human cell extracts. Rather, minichromosomes assembled on non-damaged DNA, purified from the extracts (e.g. by means of centrifugation in sucrose gradient) and subsequently exposed to DNA damaging agents, could be a suitable model for further studies. Cyclobutane pyrimidine dimers (major UV-induced DNA damage) form in similar amounts per nucleotide in the nucleosome core and linker DNA [20]. Thus, UV-radiation can be potentially used in such a study, yet possible formation of UV-induced cross-links should be considered. 
I would like to express thanks to Prof. W.T. Garrard for helpful discussions. Part of the study was completed during my stay in UT Southwestern Medical Center at Dallas.

\section{R E F E R E N C ES}

1. Sancar, A. (1996) Annu. Rev. Biochem. 65, 43-81.

2. Wood, R.D. (1996) Annu. Rev. Biochem. 65, 135-167.

3. Smerdon, M.J. (1991) Curr. Opin. Cell. Biol. 3, 422-428.

4. Mitchell, D.L. \& Nairn, R.S. (1989) Photochem. Photobiol. 49, 805-819.

5. Mann, D.B., Springer, D.L. \& Smerdon, M.J. (1997) Proc. Natl. Acad. Sci. U.S.A. 94, 2215-2220.

6. Schieferstein, U. \& Thoma, F. (1996) Biochemistry 35, 7705-7714.

7. Suquet, C. \& Smerdon, M.J. (1993) J. Biol. Chem. 268, 23755-23757.

8. Matsumoto, H., Takakusu, A. \& Ohnishi, T. (1994) Photochem. Photobiol. 60, 134-138.

9. Matsumoto, H., Takakusu, A., Mori, T., Ihara, M., Todo, T. \& Ohnishi, T. (1995) Photochem. Photobiol. 61, 459-462.
10. Ryoji, M., Tominna, E. \& Yasui, W. (1989) Nucleic Acids Res. 17, 10243-10258.

11. Wang, Z., Wu, X. \& Friedberg, E.C. (1991) J. Biol. Chem. 266, 22472-22478.

12.Gaillard, P.-H.L., Martini, E.M.-D., Kaufman, P.D., Stillman, B., Moustacchi, E. \& Almouzni, G. (1996) Cell 86, 887-896.

13. Kaufman, P.D., Kobayashi, R. \& Stillman, B. (1997) Genes Dev. 11, 345-357.

14. Shimamura, A., Jessee, B. \& Worcel, A. (1989) Methods Enzymol. 170, 603-612.

15. Widlak, P., Gaynor, R.B. \& Garrard, W.T. (1997) J. Biol. Chem. 272, 17654-17661.

16. Shimamura, A., Tremethick, D. \& Worcel, A. (1988) Mol. Cell. Biol. 8, 4257-4269.

17. Bykov, V.J., Kumar, R., Forsti, A. \& Hemminki, K. (1995) Carcinogenesis 16, 113-118.

18. Widlak, P., Bykov, V.J., Hemminki, K. \& Rzeszowska-Wolny, J. (1996) Cancer Lett. 108, 215-223.

19. Germond, J.E., Hirt, B., Oudet, P., GrossBellard, M. \& Chambon, P. (1975) Proc. Natl. Acad. Sci. U.S.A. 72, 1843-1847.

20. Mitchel, D.L., Nguyen, T.D. \& Cleaver, J.E. (1990) J. Biol. Chem. 265, 5353-5356. 